\title{
FAULT DIAGNOSTICS IN AIR INTAKE SYSTEM OF COMBUSTION ENGINE USING VIRTUAL SENSORS
}

\author{
Iwona KOMORSKA ${ }^{1}$, Zbigniew WOŁCZYNSSKI ${ }^{2}$, Artur BORCZUCH ${ }^{3}$ \\ University of Technology and Humanities in Radom, Faculty of Mechanical Engineering, \\ Department of Automotive Mechatronics \\ 1iwona.komorska@uthrad.pl, ${ }^{2}$ z.wolczynski@uthrad.pl, ${ }^{3}$ a.borczuch@uthrad.pl
}

\begin{abstract}
The method for the fault diagnosing of the air intake system of a gasoline engine, not detected by the onboard diagnostics system in a car, is described in this article. The aim is to detect and identify such faults like changes in sensor characteristic, faults of mass airflow measurement in the intake manifold or manifold leakages. These faults directly affect the air intake system performance that results in engine roughness and a power decrease. The method is based on the generation of residuals on the grounds of differences in indications of the manifold absolute pressure (MAP) and mass air flow (MAF) sensors installed in the car and the virtual, model-based sensors. The empirical model for the fault-free state was constructed at stationary operations of the engine. The residuals were then evaluated to classify the system health. Investigations were conducted for a conventional gasoline engine with port-fuel injection (PFI) and for a gasoline direct injection engine (GDI).
\end{abstract}

Keywords: combustion engine, air intake system, model-based diagnostics, virtual sensors, residual generation

\section{DIAGNOZOWANIE USTEREK W UKŁADZIE DOLOTOWYM SILNIKA SPALINOWEGO PRZY UŻYCIU WIRTUALNYCH CZUJNIKÓW}

\begin{abstract}
Streszczenie
W artykule zaproponowano metodę diagnozowania usterek w układzie dolotowym powietrza silnika benzynowego, nie wykrywanych przez system diagnostyki pokładowej samochodu. Celem jest detekcja i identyfikacja takich błędów jak zmiana charakterystyk czujników, błędy pomiaru przepływu powietrza lub nieszczelności w kolektorze dolotowym. Te usterki wpływają bezpośrednio na działanie układu dolotowego, co powoduje nierównomierność pracy silnika lub zmniejszenie jego mocy. Metoda polega na generowaniu pozostałości na podstawie różnic we wskazaniach czujników ciśnienia bezwzględnego w kolektorze i przepływomierza powietrza zainstalowanych w samochodzie oraz czujników opartych na modelu wirtualnym. Model empiryczny stanu bezawaryjnego został utworzony dla pracy silnika w stanie ustalonym. Pozostałości są następnie oceniane w celu sklasyfikowania stanu systemu. Badania przeprowadzono dla konwencjonalnego silnika benzynowego $\mathrm{z}$ wtryskiem wielopunktowym (PFI) i silnika benzynowego $\mathrm{z}$ wtryskiem bezpośrednim (GDI).
\end{abstract}

Słowa kluczowe: silnik spalinowy, system dolotowy powietrza, diagnostyka oparta na modelu, czujniki wirtualne, generowanie pozostałości

\section{INTRODUCTION}

The on-board diagnostics system in internal combustion engines constitutes an integral part of the Electronic Control Unit. The diagnostic system is oriented towards detection of faults which cause an increase of the exhaust gas emission [13]. In case of mechanical faults in the air intake system or changes of the sensor characteristics, the control system tries to mask faults adjusting - as far as possible - the engine control [1]. Such faults are often not detected by the on-board diagnostics system, however a driver notices the vehicle dynamics difference or other symptoms indicating that there really is a problem [2].
Traditional diagnostic systems compare the measurement results with fixed limits. If the sensor signal voltage does not exceed the limiting values, then the measurement is acceptable. Meanwhile, with the time the characteristics of the sensors are changed, leaks appear in the intake manifold, contacts become dirty and wet. All these can change the indications of sensors, but the signal voltage still does not reach the limits [12]. The adaptive control system of the engine will adjust the fuel dose - based on the lambda sensor indications to new conditions. That is good, because the driver with small malfunctions of his car does not have to go to the service. Sometimes, however, the driver feels that something is wrong with the engine, but the error is not detected $[4,10]$. 
The modern on-board diagnostics system often uses virtual sensors in the combustion engine $[3,6]$. Virtual sensors are computer models that combine data from other sensors and sources to recreate the data a sensor would provide. They estimate the value of physical quantities that are difficult to measure, for example toxic components in the exhaust gas while driving, or too expensive for use as a pressure sensor in the combustion chamber. Another reason for using virtual sensors is the need to multiply the measuring elements and systems for security purposes (hardware redundancy) [8]. Then, instead of additional physical, virtual sensors can be applied (software redundancy). Another reason, described here, is to diagnose faults in systems or mechatronic items. Based on the indications of other sensors recognized as efficient and relations of mathematical or statistical models, the rational indications investigated sensors are estimated and compared with the indication of the physical sensors $[7,14,15]$. Virtual sensors can be divided into static - model-based, or dynamic - using Kalman filter [16,18]. This article is an attempt to define virtual sensors for faults diagnosis not detected by the on-board diagnostics.

\section{DIAGNOSTIC METHOD}

The state of the cylinder is defined by the mass and the internal energy of air contained in the cylinder. Fig. 1 shows a cross-section of the intake manifold. The throttle angle $\alpha$ controls the flow of air mass into the manifold.

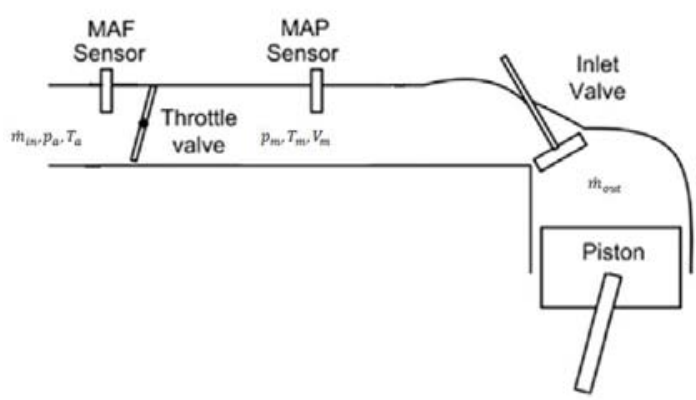

Fig. 1. Air intake system

The manifold pressure dynamics can be modelled on the basis of filling and emptying of the air behaving as a perfect gas $[5,6]$

$$
\dot{p}_{m}(t)=\frac{R T_{m}}{V_{m}}\left(\dot{m}_{\text {in }}(t)-\dot{m}_{\text {out }}(t)\right)
$$

where: $\dot{p}_{m}$ - change of manifold pressure, $T_{m}$ manifold temperature, $V_{m}$ - manifold volume, $R$ specific gas constant, $\dot{m}_{i n}$ - air mass flow into the manifold, $\dot{m}_{\text {out }}$ - air mass flow out from the manifold.

The air mass flow into the manifold is described by a function:

$$
\dot{m}_{i n}(t)=f\left(p_{m}, \alpha\right)
$$

where $p_{m}$ - manifold pressure, $\alpha$ - throttle angle, and air mass flow out from the manifold as a function:

$$
\dot{m}_{\text {out }}(t)=f\left(p_{m}, n\right)
$$

where $n$ - engine speed.

At stationary engine operations, it can be assumed that

$$
\dot{m}_{\text {in }}(t)=\dot{m}_{\text {out }}(t)=\dot{m}_{a}(t)
$$

where $\dot{m}_{a}$ - air mass flow rate measured with air flowmeter.

At stationary engine operation one of the engine load measure: throttle angle $\alpha$, air flow $\dot{m}_{a}$, manifold pressure $p_{m}$, can be estimated from the remaining measurements and the rotational engine speed $n[9]$.

The SI engine is controlled by the relative air supply mass $m_{a}$. This is done by throttling the air into the engine. The relative fuel supply mass $m_{f}$ is subsequently regulated by the engine management system to maintain the desired air-fuel ratio $\lambda$. The range of $\lambda$ is limited by the ability to inflame airfuel mixtures by spark ignition. The conventional port fuel injection (PFI) engines operate on approximately homogenous mixtures $(0.9<\lambda$ $<1.3)$.

The manifold absolute pressure sensor supplies the instantaneous manifold pressure information to the engine electronic control unit. A fuel-injected engine may alternatively use the mass airflow sensor to find out the mass flow rate of the air entering the fuel-injected internal combustion engine. The air mass information is necessary for the engine control unit to balance and deliver the correct fuel mass to the engine.

Using averaged values of signals: throttle position $\alpha$, engine rotational speed $n$, manifold pressure $p_{m}$ and air mass flow $\dot{m}_{a}$, the virtual sensors $p_{m-v 1}, p_{m-v 2}, \dot{m}_{a-v 1}, \dot{m}_{a-v 2}$ can be defined. For this purpose the look-up tables, that were prepared in the empirical way, were used:

$$
\begin{gathered}
\dot{m}_{a-v 1}=f_{1}(\alpha, n) \\
p_{m-v 1}=f_{2}(\alpha, n) \\
\dot{m}_{a-v 2}=f_{3}\left(n, p_{m}\right) \\
p_{m-v 2}=f_{4}\left(\alpha, \dot{m}_{a}\right)
\end{gathered}
$$

During simulations with the model for steady state, following residuals are generated:

$$
\begin{gathered}
r_{1}=\dot{m}_{a}-f_{1}(\alpha, n) \\
r_{2}=p_{m}-f_{2}(\alpha, n) \\
r_{3}=\dot{m}_{a}-f_{3}\left(n, p_{m}\right) \\
r_{4}=p_{m}-f_{2}\left(\alpha, \dot{m}_{a}\right)
\end{gathered}
$$

The $i$-th residual indicator $R$ is established in the following way: 


$$
R_{i}=\left\{\begin{array}{lll}
0 & \text { if } & r_{i} \leq u \\
1 & \text { if } \quad & r_{i}>u
\end{array}\right.
$$

where $u$ is the model uncertainty.

The components of the model uncertainty are: measurement errors, uniqueness of working cycles of engine.

The method of fault diagnostic is presented in Fig.2. The algorithm was implemented in the Matlab Simulink software.

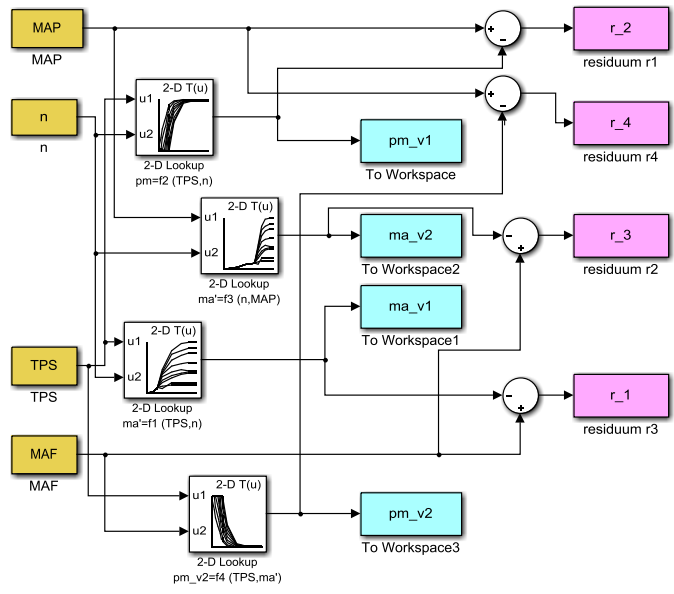

Fig. 2. Virtual sensors and residuals generation

\section{EXPERIMENTAL SETUP}

To validate the method two steady state experiment was performed.

The first experiment was performed on the fourcylinder spark ignition conventional engine of portfuel-injection (PFI). The engine was positioned on the laboratory test bed (Fig.3).

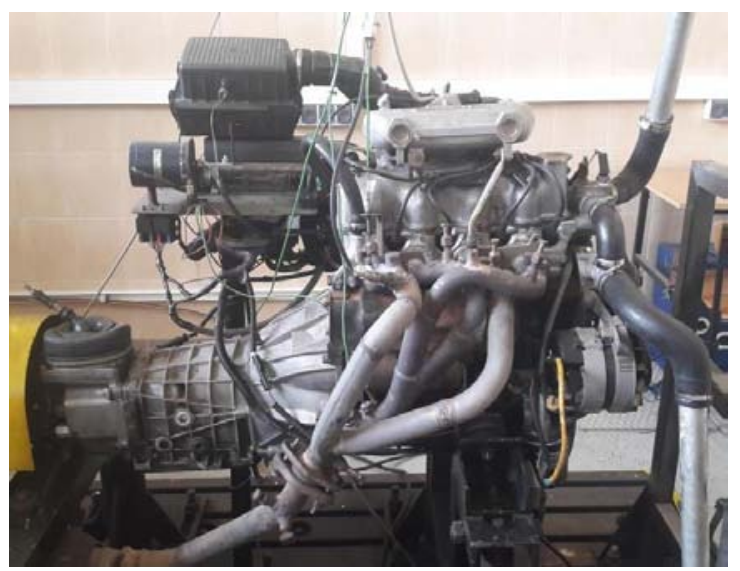

Fig. 3. Investigated object - PFI engine

Conventional manifold injection engines generate air-fuel mixture in the intake manifold. The calculation of air mass into cylinder is based on the manifold pressure sensor. The engine speed is calculated based on the induction-type sensor and the throttle valve angle is detected with potentiometer-type sensor. The air flow meter
(MAF sensor Bosch MFM5) was mounted additionally.

The second investigation was conducted on the four-cylinder spark ignition engine of a gasoline direct injection (GDI) of passenger car Mitsubishi Carisma [11,12] (Fig.4).

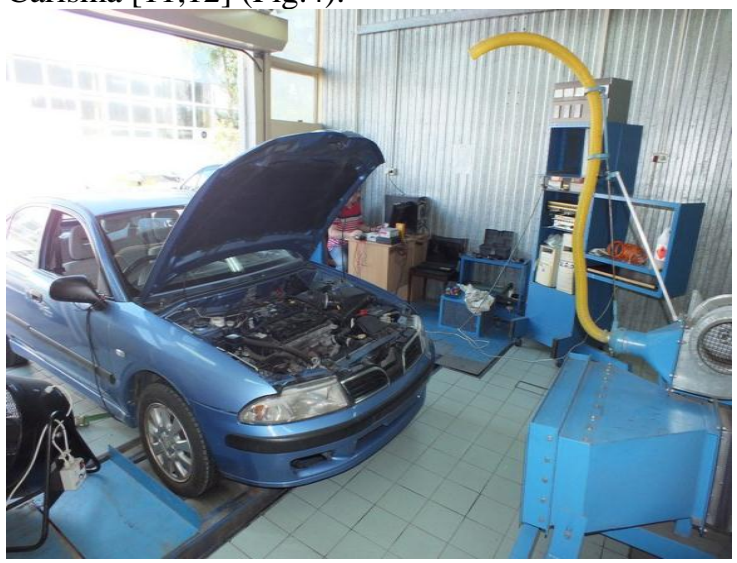

Fig. 4. Investigated object - GDI engine

The GDI engine is more complex than an ordinary PFI engine and therefore requires a more advanced control system. GDI engines generate airfuel mixture in the combustion chamber similar to the diesel engines [17]. They operate in two main modes: homogenous mode and stratified mode. The mode that should be used is decided by engine load and engine speed. The stratified charge of the cylinder is used in combination with extremely lean air-fuel mixtures to reduce fuel consumption. In homogenous operation at $\lambda \leq 1$, the GDI engine for the most part behaves the same as a PFI engine.

The calculation of air mass into cylinder is based on the Karman vortex-type mass airflow sensor indication (MAF sensor). The engine speed is calculated based on the induction-type sensor and the throttle valve angle is detected with the potentiometer-type sensor. The manifold pressure sensor was mounted additionally.

The solutions applied in this vehicle such as a design and engine equipment are commonly used in the automotive market This substantiates the assumption as to the universality of the conclusions and trends resulting from the investigations. The car was positioned on a chassis dynamometer.

It was possible to brake a vehicle or the engine with the given moment, or accelerated to the given speed. In such way the vehicle engine was loaded to the required and simultaneously constant speed $n$ at various throttle openings $\alpha$.

Tests were based on recording signals in 10seconds stretches from selected sensors of the engine at stationery operation. Recording was performed by the computer system of collecting data consisted of the computer with the measuring equipment OCTOPUS CompuScope 8380 of the GAGE Company. This device allows sampling of all signals with a frequency from $1 \mathrm{kHz}$ to $10 \mathrm{MHz}$ 
and the resolution of 14 bits. The following voltage signals were recorded:

- crankshaft position sensor

- camshaft position sensor

- mass airflow (MAF) sensor - an additional sensor for PFI engine, not used as a standard in this engine

- throttle valve position (TPS) sensor

- manifold absolute pressure (MAP) sensor - an additional sensor for GDI engine, not used as a standard in this engine

- output signal of the analyser of the composition of combusted mixture, MEXA700 $\lambda$ of the HORIBA Company

In addition, temperatures of the liquid cooling the engine and of the sucked-in air were recorded, for each stationary engine operation point.

Tests were carried out for equally spaced engine speeds and throttle positions. The throttle angle was expressed in percentages, where 0 means the total closing and $100 \%$ the total opening of the throttle. Since signals were recorded in steady states the average values of the above signals were determined for each second of the recording, it means 10 values for the given point $(n, \alpha)$.

Fig. 5 shows the relationship between three indications describing the engine load: throttle position $\alpha$, manifold pressure $p_{m}$ and air mass flow rate $\dot{m}_{a}$ at various engine speeds $n$.

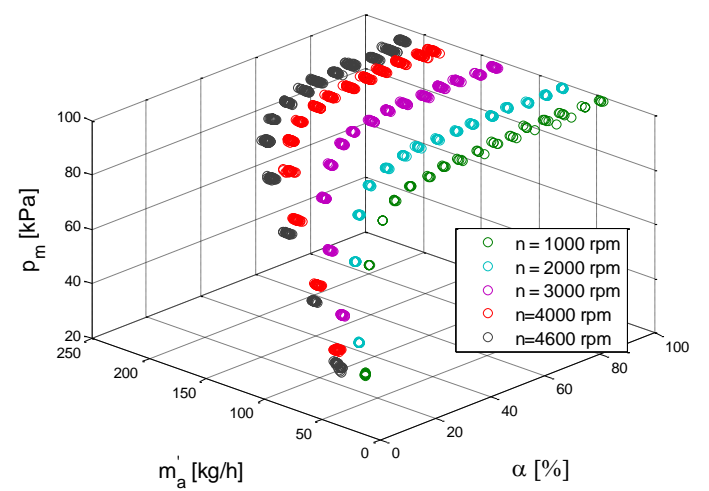

Fig. 5. Relations between throttle position $\alpha$, mass airflow in manifold $m_{a}$ ' and manifold absolute pressure

$p_{m}$ at constant engine speed $n$ for PFI engine

The surfaces described by equation (5-8) for PFI engine are presented in Fig. 6, together with the marked measuring points. To represent the functions $f_{1} \ldots f_{4}$, the interpolation in the maps or polynomial equations can be used.

To validate the diagnostic method, measurements and calculation procedures were performed for three simulated faults:

1. Mass air flow meter fault caused by chocking the part of the flow channel, from the air filter side.

2. Throttle angle sensor fault caused by characteristic change that occurring e.g. in a situation of wetting the electrical installation or sensor flooding.
3. Manifold air leakage.

a)

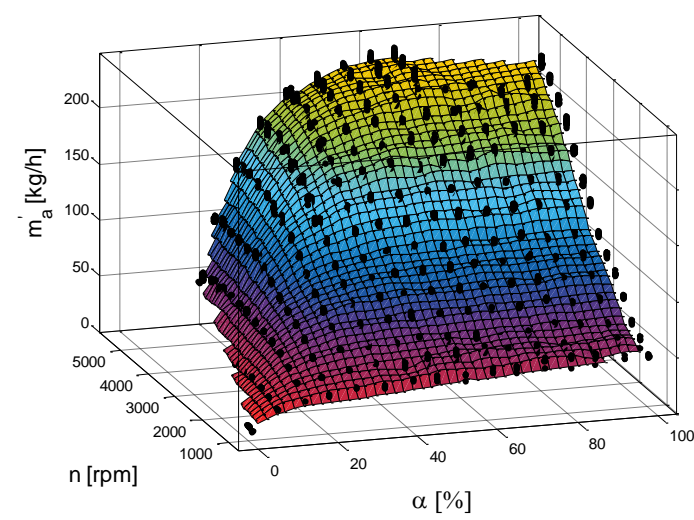

b)

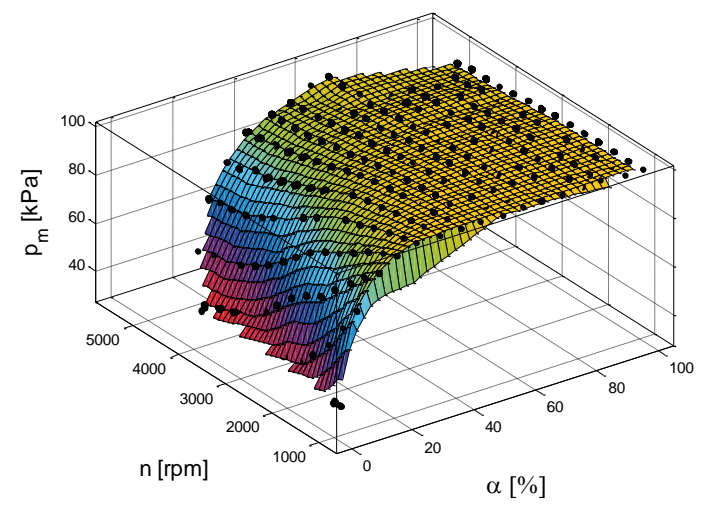

c)

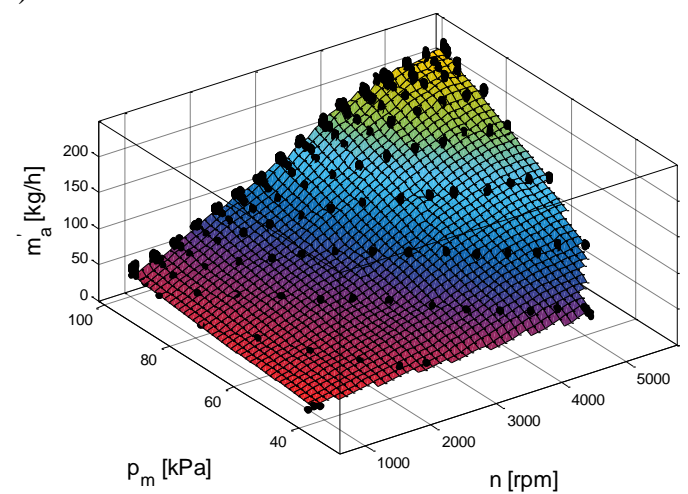

d)

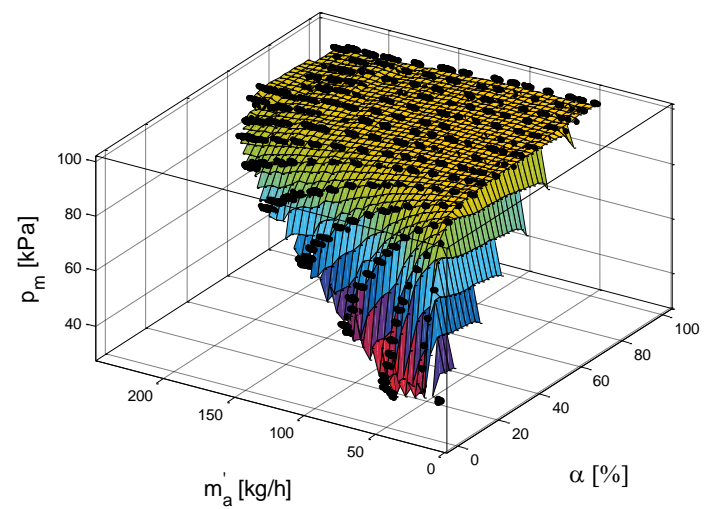

Fig. 6. Relations between throttle position $\alpha$, rotational speed $n$, mass airflow in manifold $m_{a}$ ' and manifold absolute pressure $p_{m}$ for PFI engine 
In all these situations the on-board diagnostics (OBD) system did not record an error, while the user could notice the change in the engine operation in a form of roughness or a power loss at higher rotational speeds of the engine.

\section{FAULTS ANALYSIS}

\subsection{Obscuration of the intake manifold}

Partial obscuration of the intake manifold caused flow disturbances and malfunction of the Karman vortex mass air flow meter in the GDI engine. Large fluctuations in the air mass index caused oscillations in the fuel dose and - in consequence - uneven working of the engine. Consequently, this resulted in uneven rotational speed and variations in mixture composition.

The indicated flow was so small that the engine changes into supplying by a very lean mixture (recorded air-fuel ratio $\lambda>1$ ). The adaptive control system tried to adjust the fuel dose based on the lambda sensor indication. Average air mass flow rate values were lower than at fault-free operation.

The adaptive control system tried to adjust the fuel dose based on the lambda sensor indication. Average air mass flow rate values were lower than at fault-free operation $f_{1}$ (Fig.7a) and $f_{2}$ (Fig.7b) described respectively in equations (5) and (6) together with measurement results for the fixed throttle position.
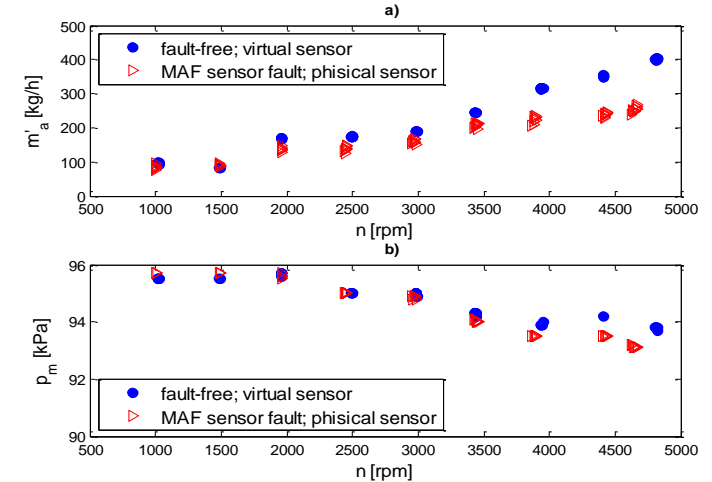

Fig. 7. Comparison of sensors indications (GDI engine) for two states: fault-free (virtual sensor) and MAF sensor fault (physical measurement) at the throttle opening of $85 \%$ a) MAF sensor, b) MAP sensor

The intake manifold pressure is within error limits of the model, while the mass air flow is lower than it results from the model for the whole range of engine loads. The difference can be seen especially for high rotational speeds. The similar results are for the PFI engine (Fig.8).
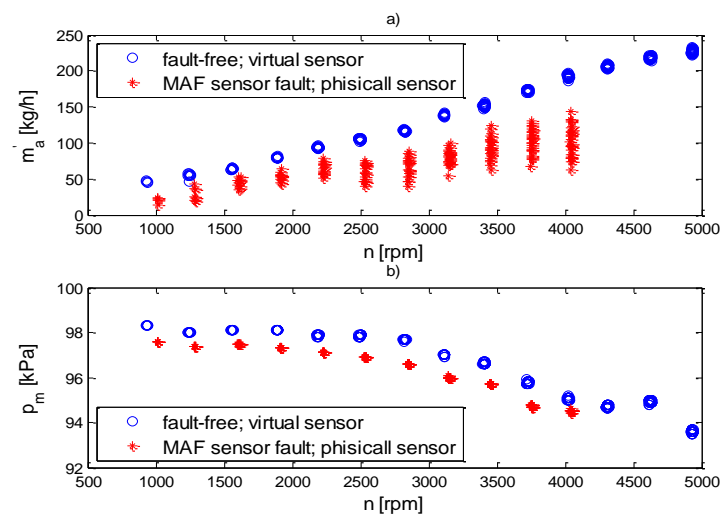

Fig. 8. Comparison of sensors indications (PFI engine) for two states: fault-free (virtual sensor) and MAF sensor fault (physical measurement) at the throttle opening of $100 \%$

a) MAF sensor, b) MAP sensor

Relations between the MAP and MAF sensors indications and rotational speed for the PFI engine described by $f_{3}$ function (equation (7)) are shown in Fig.9a. The surface shows the virtual sensor indications. When the manifold is partially obscured the MAF sensor is faulty and the difference between physical and virtual sensor occurs, especially for a small throttle opening angle. Fig.9b shows the cross-sections of Fig.9a for fixed rotational speeds of 2000 and $4000 \mathrm{rpm}$.

a)

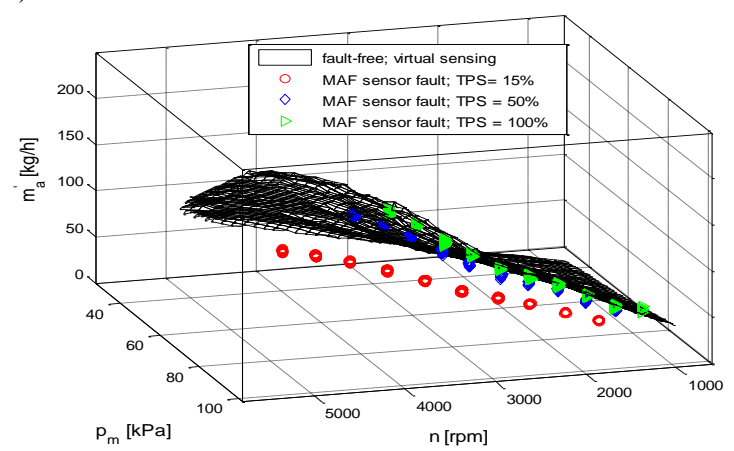

b)

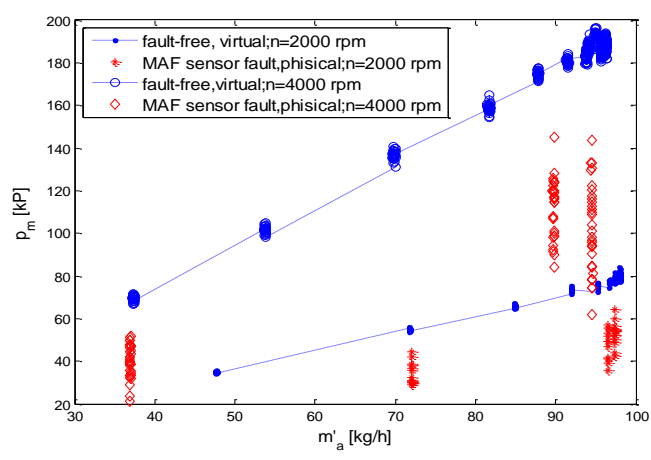

Fig. 9. Comparison of sensors indications (PFI engine) for two states: fault-free (virtual sensor) and MAF sensor fault (physical sensor) a) $3 \mathrm{D}$ view b) Cross-section at the engine speed 2000 and $4000 \mathrm{rpm}$ 
Relations between the MAP and MAF sensor indications and throttle positions TPS for the PFI engine described by $\mathrm{f} 4$ function (equation (8)) are shown in Fig.10a. The surface shows the virtual sensor indications. When the manifold is partially obscured the difference between physical and virtual sensor occurs, especially for a small throttle opening angle. Fig.10b shows the cross-sections of Fig.10a for fixed throttle opening of $15 \%$ and $100 \%$.

a)

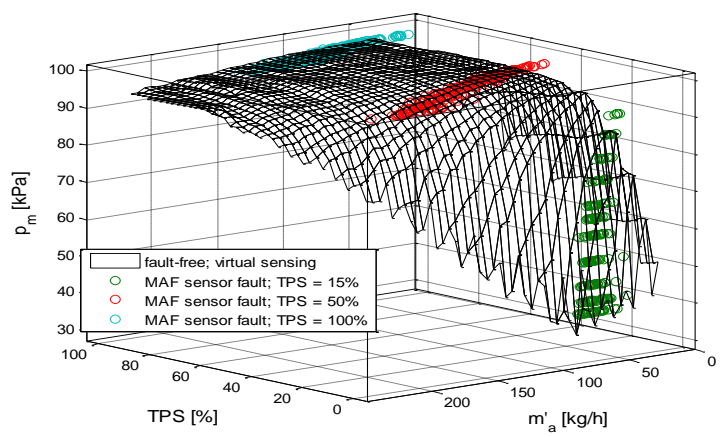

b)

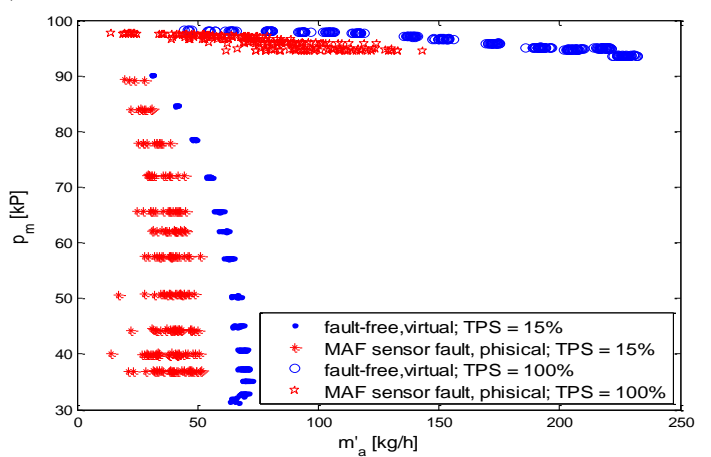

Fig. 10. Comparison of sensors indications (PFI engine) for two states: fault-free (virtual sensor) and MAF sensor fault (physical sensor) a) 3D view, b) Cross-section at the throttle opening of $15 \%$ and $100 \%$

\subsection{Fault of throttle position sensor}

In the second case - characteristic changes of the throttle angle sensor - the fault was simulated by bypassing the output of the second throttle channel with the resistor of $5.57 \mathrm{k} \Omega$. This can correspond to the situation when the sensor is flooded or electrical installation wetted. A careful car driver feels it as a small power decrease of the engine.

Fig. 11 shows the results of measurements of the intake manifold pressure and the mass air flow for the described failure compared with the virtual sensor indications at $50 \%$ of the throttle opening. Fig.11a and 11b show the difference between the results obtained in physical and virtual measurements as $f_{1}$ and $f_{2}$ functions, respectively equation (5) and (6). In this case, in the range of medium loads and high rotational speeds $(n>4000$ $\mathrm{rpm})$, a significant increase of signal indications from the pressure sensor as compared with the model sensor is observed, as well as a decrease of the mass air flow sensor indications as compared with the model.
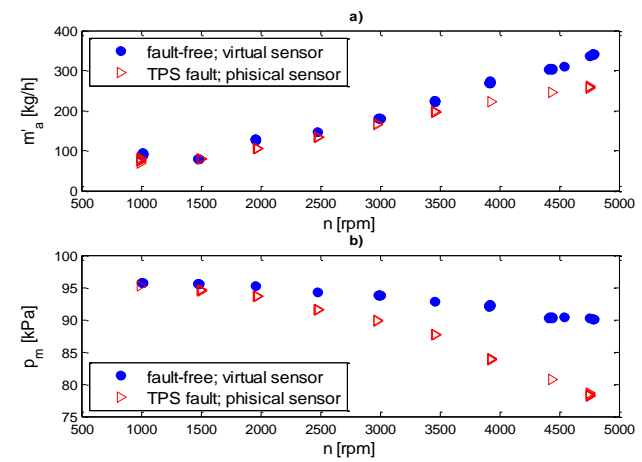

Fig. 10. Comparison of sensors indications (GDI engine) for two states: fault-free (virtual sensor) and throttle position sensor fault (physical sensor) at throttle opening of $50 \%$ a) MAF sensor, b) MAP sensor

\subsection{Leakage of the intake manifold}

The third case constitutes the air leakage of the intake manifold, which can cause such effects as: hissing noise, engine stumbling, rough or fast idling or stalling, poor gas mileage. Tests were performed at a small leakage, at which the on-board diagnostics system did not record any error. The mass air flow indicated the correct value, while the pressure sensor indicated underrated value as compared with the corresponding model, especially in the range of high loads.

Fig. 12 shows the results of measurements for the GDI engine of the intake manifold pressure and the mass air flow for the described failure at $85 \%$ of the throttle opening.
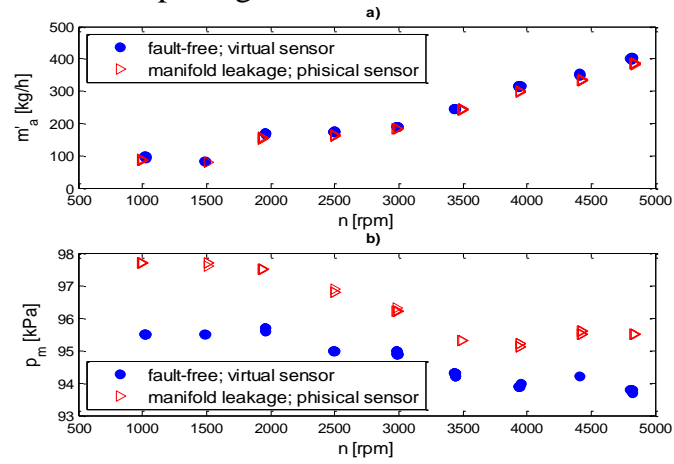

Fig. 12. Comparison of sensors indications (GDI engine) for two states: fault-free (virtual sensor) and manifold leakage (physical measurement) at the throttle opening of $85 \%$ a) MAF sensor, b) MAP sensor

The manifold pressure signal values are, in this case, larger than in the fault-free state for all engine speeds, while the air mass values remain similar. The fuel injection control of the tested engine is based on indications of the MAF sensor. In this case the adaptive control system will try to adjust the fuel dose based on the lambda sensor indication.

For the PFI engine the pressure sensor fault is visible especially for a small throttle opening (Fig.13). 


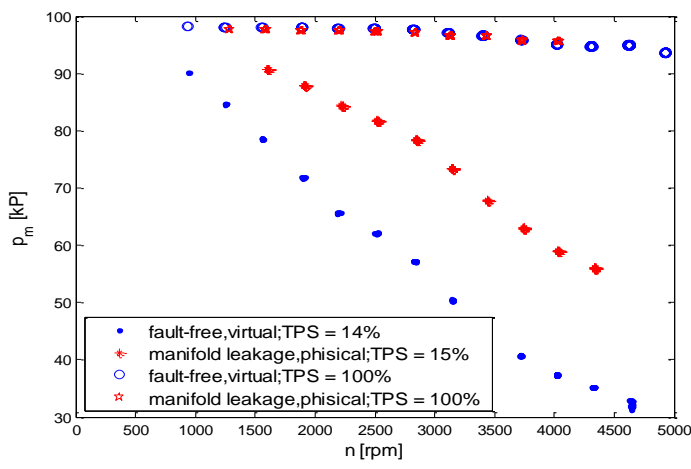

Fig. 13. Comparison of MAP sensor indications (PFI engine) for two states: faultfree (virtual sensor) and manifold leakage (physical measurement) at the throttle opening of $15 \%$ and $100 \%$

The relation between the MAP and MAF sensors and rotational speed indications for faultfree (surface of virtual sensing obtained with $f_{3}$ function) and the manifold leakage shows the difference between physical and virtual sensors (Fig.14).

a)

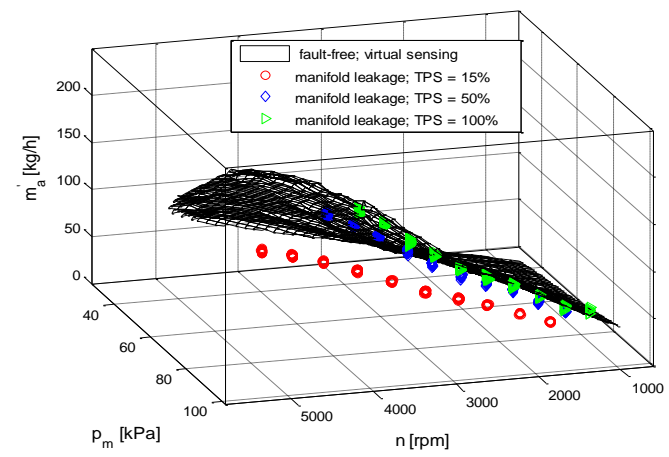

b)

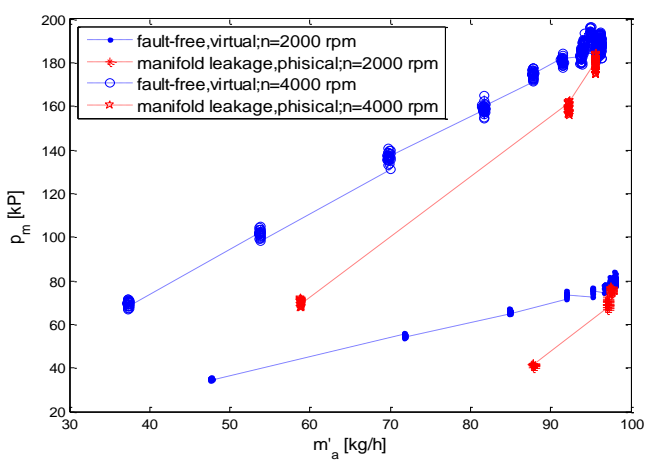

Fig. 14. Comparison of sensors indications (PFI engine) for two states: fault-free (virtual sensor) and manifold leakage (physical sensor)

a) $3 \mathrm{D}$ view, b) Cross-section at the engine speed 2000 and $4000 \mathrm{rpm}$

The relation between the MAP and MAF sensors and throttle position indications for faultfree (surface of virtual sensing obtained with $f_{4}$ function) and the manifold leakage shows no difference between physical and virtual sensors.

\subsection{Residuals generation}

During simulations of the model four residuals $r_{1}, r_{2}, r_{3}, r_{4}$ described with equations (8 -11) were generated. Multiple residuals could be created, but in this simple example they do not provide any new information.

The residuals described in formulas $(9-12)$ were calculated and residual indicators described in formula (13) were summarised in Table 1.

Table 1. Residual indicators

\begin{tabular}{|r|r|r|r|}
\hline $\begin{array}{r}\text { Residual } \\
\text { indicator }\end{array}$ & $\begin{array}{r}\text { Obscured } \\
\text { manifold }\end{array}$ & TPS fault & $\begin{array}{r}\text { Manifold } \\
\text { leakage }\end{array}$ \\
\hline R1 & 1 & 1 & 0 \\
\hline R2 & 0 & 1 & 1 \\
\hline R3 & 1 & 0 & 1 \\
\hline R4 & 1 & 1 & 0 \\
\hline
\end{tabular}

The residuals can be in two states: 1 - means that the difference between the data and model output surpasses the value of the model uncertainty, 0 - means that the difference lies within the model error limits. Calculating of the method uncertainty is a very important problem and is the subject of a separate publication.

\section{CONCLUSIONS}

The proposition of faults diagnostics in the air intake manifold of the gasoline direct injection engine is presented in the hereby paper. The method is based on the generation of residual indicators on the grounds of differences in indications of the MAP and MAF sensors installed in the car and the virtual model-based sensors. The diagnostics is performed at the steady state of engine operations. Four maintenance states were investigated. Three tested faults were not detected by the OBD system, while a user could notice e.g. an engine power decrease. Both sensors, mass air flow and pressure, which are applied interchangeably in vehicles, are necessary to differentiate the state by the presented method.

However, only two sensors are commonly installed in cars. In Mitsubishi (GDI engine) the throttle angle and mass air flow are measured, while in the PFI engine the throttle angle and manifold pressure sensors are used. Based on measurements from two sensors, functions $f_{3}$ and $f_{4}$ cannot be determined. However, the TPS sensor error can be ruled out by comparing its indication with the second redundant TPS sensor.

The residuals generation should be repeated for several steady-state operation condition (different rotational speeds and loads), as errors are not always reflected in measurements. The defect can be detected if the corresponding residuum is greater than the uncertainty of the model.

Further research will concern the development of the hybrid model of the tested engine and formation of new virtual sensors and residuals based on transient states of engine operations. 


\section{REFERENCES}

1. Dąbrowski Z Madej H. Masking mechanical damages in the modern control systems of combustion engines. Journal of Kones Powertrain and Transport 2006; 13(3): 53-60.

2. Dąbrowski Z, Zawisza M. Investigations of the vibroacoustic signals sensitivity to mechanical defects not recognised by the OBD system in diesel engines. Mechatronic Systems, Mechanics and Materials. Solid State Phenomena 2012; 180: 194199.

3. Dutka A, Javaherian H, Grimble M. Model-based engine fault detection and isolation. Proceedings of American Control Conference ACC '09 2009: 4593 $-4600$.

4. Figlus $\mathrm{T}$, Konieczny $€$, Burdzik $\mathrm{R}$, Czech $\mathrm{P}$. Assessment of diagnostic usefulness of vibration of the common rail system in the diesel engine. Vibroengineering Proceedia 2015; 6: 185- 189.

5. Franchek MA, Buehler PJ, Makki I. Intake air path diagnostics for internal combustion engines. Journal of Dynamic Systems, Measurement and Control 2007; 129(1): 32-40.

6. Guzzella L, Onder C. Introduction to Modelling and Control of Internal Combustion Engine Systems. Springer; ETH Zurich; 2004.

7. Isermann R. Model-based fault-detection and diagnosis - status and applications. Annual Reviews in Control 2005; 29: 71-85.

8. Jongeneel J, Nijmeijer H, Manzie C, Nesic D. Input redundant internal combustion engine with linear quadratic Gaussian control and dynamic control allocation. Internal Report. Eindhoven University of Technology; Eindhoven, Netherlands; 2009.

9. Kiencke U, Nielsen L. Automotive Control Systems. For Engine, Driveline, and Vehicle. SpringerVerlag; Berlin Heidelberg; 2005.

10. Komorska I, Puchalski A. On-board diagnostics of mechanical defects of the vehicle drive system based on the vibration signal reference model. Journal of Vibroengineering 2013; 15(1): 450-458.

11. Komorska I, Wołczyński Z. Fault Diagnostics of Air Intake System of the Internal Combustion Engine. ICTD-CMMNO 2016 Congress; Gliwice 1216.09.2016.

12. Komorska I, Wołczyński Z, Borczuch A. Modelbased analysis of sensor faults in SI engine. Combustion Engines 2017; 169(2): 146-151.

13. Merkisz J, Pielecha J, Radzimirski S. New trends in emission control in the European Union. Springer; 2014.

14. Nyberg M, Nielsen L. Model Based Diagnosis for the Air Intake System of the SI-Engine. SAE Technical Paper 970209; 1997. http://dx.doi.org/10.4271/970209.

15. Nyberg M. Model-based diagnosis of an automotive engine using several types of fault models. IEEE Transactions on Control Systems Technology 2002; 10(5): $679-689$. http://dx.doi.org/10.1109/TCST.2002.801873.

16. Puchalski A, Komorska I. On-line Fault Diagnosis of Automotive Powernets by Kalman Filtering. Key Engineering Materials 2014; 588: 209-213.

17. Reif K. Gasoline Engine Management. Systems and Components. Springer-Vieweg; 2015. http://dx.doi.org/10.1007/978-3-65803964-6.

18. Wenzel TA, Burnham KJ, Blundell MV. Kalman filter as a virtual sensor: applied to automotive stability systems. Transactions of the Institute of Measurement and Control 2007; 29(2): 95-115.

Received 2017-09-14

Accepted 2017-12-04

Available online 2017-12-18
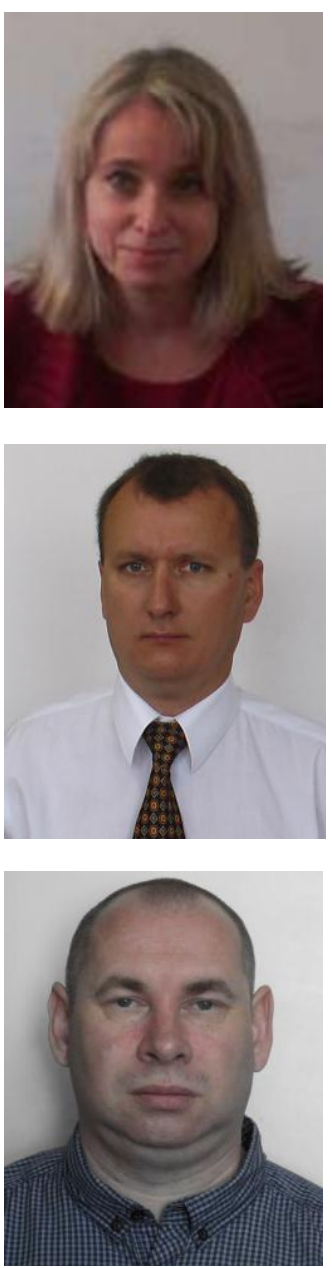

Iwona KOMORSKA, DSc., DEng. - Professor in the Faculty of Mechanical Engineering at University of Technology and Humanities in Radom. Her current research interests include signal processing, modelling \& simulation, automotive mechatronics.

\section{Zbigniew}

WOLCZYŃSKI, DEng. Doctor in the Faculty of Mechanical Engineering at University of Technology and Humanities in Radom. His current research interests include electronics and automotive mechatronics.

Artur BORCZUCH, MEng. - Technical support engineer in the Faculty of Mechanical Engineering at University of Technology and Humanities in Radom. His current research interests include automotive engineering. 